\title{
PERSPECTIVES ON INTERNATIONAL DISPUTE SETTLEMENT FROM A PARTICIPANT
}

\author{
Rt Hon Sir Geoffrey Palmer SC*
}

\begin{abstract}
The author uses a variety of examples to explore international dispute settlement processes and to provide some suggestions for improvement. These examples, drawing on the author's own career and New Zealand's developing role in the international community, include the Rainbow Warrior affair, nuclear testing issues, the Gaza Flotilla inquiry and experiences at the International Whaling Commission.
\end{abstract}

\section{INTRODUCTION}

This paper draws on personal experience with a number of unrelated international disputes in order to provide some insights into the methods of settling international disputes and a way in which these may be improved. The examples used are:

- the issue of nuclear testing in French Polynesia that went to the International Court of Justice twice;

- $\quad$ the dispute with the United States over New Zealand's anti-nuclear policy;

- $\quad$ New Zealand's dispute with France over the Rainbow Warrior affair;

- $\quad$ the United Nations inquiry into the Gaza Flotilla incident of 31 May 2010; and

- $\quad$ efforts to reach diplomatic rapprochement at the International Whaling Commission.

* Barrister; Distinguished Fellow, Faculty of Law and New Zealand Centre for Public Law, Victoria University of Wellington. I wish to express my appreciation for comments on a draft of this paper made by Elana Geddis, Colin Keating, Gerard van Bohemen and Rachel Opie. They are not, however, responsible for the contents. I am also grateful for valuable conversations on aspects of the subject matter with Professor Margaret Wilson and Gerald Hensley. 


\section{METHODS OF DISPUTE SETTLEMENT}

The Charter of the United Nations has as one of its central purposes the requirement set out in art 2(3) that all members are to settle their international disputes by peaceful means in such a manner that international peace and security, and justice, are not endangered. Pacific settlement of disputes provisions appear in ch VI. Article 33(1) imposes a specific legal principle on member States. It provides:

The parties to any dispute, the continuance of which is likely to endanger the maintenance of international peace and security, shall, first of all, seek a solution by negotiation, enquiry, mediation, conciliation, arbitration, judicial settlement, resort to regional agencies or arrangements, or other peaceful means of their own choice.

A number of threshold issues exist with this provision. When are parties in dispute and how do they know? Opposing views, disagreements between States or a sense of grievance do not necessarily mean that a dispute exists. In international law 'dispute' tends to be treated as a technical term. In a 1924 case, the Permanent Court of International Justice defined dispute "as a disagreement on a point of law or fact, a conflict of legal views or interests between two persons."1 In another case the International Court of Justice said the judgment of the Court had to have some practical consequences "in the sense that it can affect existing legal rights or obligations thus removing uncertainty from their legal relations."2 Some specificity of differences is required and some form of contest. New Zealand has reason to understand the need for a dispute. Essentially it lost its Nuclear Tests Case before the International Court of Justice in 1974 when a French Government media release published before the judgment, saying France would cease atmospheric nuclear testing in the Pacific, meant in the view of the Court that the dispute with France no longer existed. ${ }^{3}$

It is an important ingredient of preparation to think carefully about what precisely the dispute is about. How the subject matter of a dispute is framed or characterised and the avenues both legal and political available to resolve it can be critical. The framing often determines the law that applies to the dispute. An example that resonates in New Zealand is the Southern Bluefin Tuna case. ${ }^{4}$ There it was necessary to decide early whether there was a dispute about the interpretation of the United Nations Convention on the Law of the Sea (UNCLOS) or whether it was a dispute that

1 Electricity Company of Sofia and Bulgaria (Belgium v Bulgaria) (Preliminary Objection) (1939) PCIJ (series A/B) No 77 at 83.

2 Cameroon v United Kingdom (Preliminary Objection) [1963] ICJ Rep 15 at 33-34.

3 Nuclear Tests Case (New Zealand v France) [1974] ICJ Rep 457 at 474-476.

4 Southern Bluefin Tuna (Australia v Japan) (Jurisdiction and Admissibility) (2000) 39 ILM 1539. 
revolved around the interpretation of the Southern Bluefin Tuna Convention. ${ }^{5}$ This decision was a key factor in determining whether jurisdiction existed for the case to be heard.

The second preliminary issue that arises is whether the dispute endangers the maintenance of international peace and security. Clearly many bilateral disputes between nations will not fall into this category, although some will. The way in which ch VI is framed contemplates the Security Council forming views on disputes and taking any of a number of actions set out:

- $\quad$ calling upon the parties to settle their dispute when it deems necessary;

- $\quad$ investigating any dispute or any situation that might lead to international friction;

- $\quad$ recommending appropriate procedures or methods of adjustment;

- $\quad$ dealing with disputes referred by the parties where they have failed to settle it; and

- if all the parties so request making recommendations with a view to the pacific settlement of the dispute.

Furthermore the Charter provides that any member may bring any dispute to the attention of the Security Council or the General Assembly. Article 99 enables the Secretary-General to bring to the attention of the Security Council any matter that in his opinion may threaten the maintenance of international peace and security.

The hierarchy of methods with which to arrive at a resolution of the dispute is extensive - from negotiation to adjudication and every modern method of dispute settlement in between. ${ }^{6}$ Each of the enumerated methods has its own features, its own literature and its own practice. Negotiations are the standard fare of diplomacy and usually the first step. ${ }^{7}$ Negotiation covers different categories of dispute. New law is made in treaties that are negotiated. Disputes both bilateral and multilateral are also settled by negotiation. States like negotiations because they remain in the driver's seat in a manner that they do not in third-party adjudication. But to negotiate is not necessarily to reach an agreement, even though that is the aim.

5 Convention for the Conservation of Southern Bluefin Tuna 1994 NZTS 11 (signed 10 May 1993, entered into force 20 May 1994).

6 JG Merrills International Dispute Settlement (5th ed, Cambridge University Press, Cambridge, 2011); Francisco Orrego Vicuña International Dispute Settlement in an Evolving Global Society: Constitutionalization, Accessibility, Privatization (Cambridge University Press, Cambridge, 2004); Duncan French, Matthew Saul and Nigel White (eds) International Law and Dispute Settlement: New Problems and Techniques (Hart Publishing, Oxford, 2010); L Oppenheim International Law: A Treatise (7th ed, Longmans, London, 1952) vol 2 at [3-120] is still worthy of examination.

7 I shall not dwell on what diplomacy is. I recall as a student having to read Harold Nicolson Diplomacy (3rd ed, Oxford University Press, New York, 1964). See also Jean-Robert Lequey-Feilleuz The Dynamics of Diplomacy (Lynne Rienner, Boulder, 2009) where an extensive and useful bibliography is set out at 369389. 
One trouble with negotiations is that they can be endless - not resolving the dispute now is often better than concluding there has been a failure to resolve it. But negotiation can be quick if there is a will and it is certainly flexible. Of course negotiations have to be conducted in good faith but there is large elasticity about what may or may not constitute good faith in the particular circumstances and that issue can become the subject of dispute. Allegations of bad faith are frequently made in my experience but not often followed through on. Obviously bilateral negotiations are different from multilateral ones; group dynamics play an important role in the latter category.

Inquiry, mediation and conciliation are all related. The Hague Conventions for the Pacific Settlement of International Disputes in 1899 and 1907 devised Commissions of Inquiry, the function of which was to investigate the facts of a dispute and make a report setting them out. ${ }^{8}$ This is not in the nature of an adjudication. It is left up to the parties to decide what to do with it. Under the Hague rules a Commission of Inquiry would be set up on each occasion by agreement between the nations involved. ${ }^{9}$ This method was famously used in the Dogger Bank case between Great Britain and Russia arising out of an attack by Russian warships on British fishing vessels in the North Sea. ${ }^{10}$ Such an arrangement is open under the provision relating to inquiry in art 33.

Mediation may be regarded as a method that has a more active third-party involvement, not to adjudicate on the dispute but to try and help the parties reach agreement. This can be done in a number of ways. Mediators can put up proposals to the parties. They can cajole. They can help the parties see reason and encourage a rational approach. They can attempt to instil a sense of fairness in the parties. They can point out weaknesses in the approach of each side. As a dispute settlement method it is highly flexible and it is not inhibited by legal structures surrounding it. But finding acceptable mediators to deal with disputes between nation States is frequently difficult.

Apart from the reference in art 33 to conciliation, dispute settlement by conciliation is provided for in both the Vienna Convention on the Law of Treaties and the Vienna Convention on Succession of States in respect of Treaties. ${ }^{11}$ Conciliation under the Treaties Convention may be requested by

8 Hague Convention for the Pacific Settlement of International Disputes 1 Bevans 230 (signed 29 July 1899, entered into force 4 September 1900); Hague Convention for the Pacific Settlement of International Disputes 1 Bevans 577 (signed 18 October 1907, entered into force 26 January 1910).

9 There is an issue of orthography in relation to the terms 'Enquiry' and 'Inquiry'. The New Zealand Oxford Dictionary (Oxford University Press, Melbourne, 2005) at 356 contains a helpful note on usage: "A useful distinction exists between enquire and inquire, although some people use these two terms interchangeably. Enquire is best used to mean 'to ask' in general contexts, while inquire is best reserved to mean 'to make a formal investigation ... The same distinction exists between enquiry and inquiry." I have standardised the spelling to 'inquiry'. The international practice is variable.

10 Incident in the North Sea (United Kingdom v Russia) (1905) 1 Hague Court Reports 403.

11 Vienna Convention on the Law of Treaties 1155 UNTS 331 (opened for signature 23 May 1969, entered into force 27 January 1980); Vienna Convention on Succession of States in Respect of Treaties 1946 UNTS 3 (opened for signature 23 August 1978, entered into force 6 November 1996). 
any party to the Convention. ${ }^{12}$ It is then referred to a Conciliation Commission that is constituted by appointing four conciliators, one each from the States in dispute and one each drawn from a list maintained by the Secretary-General not of the nationality of the disputing States. Those four appoint a fifth who is the chair. The aim is to facilitate an amicable settlement. The Commission hears the parties, examines the claims and objections and makes proposals to the parties. Again a procedure for conciliation can be set up between contending States where there is a will to do so. The Vienna Convention for the Protection of the Ozone Layer provides that a Conciliation Commission shall be created upon the request of one of the parties to a dispute. ${ }^{13}$ The Commission is composed of an equal number of members appointed by each party concerned and a chair chosen jointly by the members appointed by each party. The Commission renders a final and recommendatory award that the parties must consider in good faith. There is also provision for it in Annex V(1) of the UNCLOS. ${ }^{14}$ The General Assembly provided Model Rules for the Conciliation of Disputes between States comprising various aspects of conciliation. ${ }^{15}$

Arbitration is a formal and binding method of adjudication applying the law. But the proceedings are usually held in private thus making it more attractive to political leaders than adjudication in a court. The arbitrators are judges. Arbitrators are usually appointed by the parties but they are not subject to their orders as to what to decide. Arbitration can be more flexible than adjudication in the sense that it is possible for the parties to frame the issues to be decided and the procedure to a greater degree than with adjudication in a court. Arbitration is used perhaps less than it was. There were more before the First World War than between the Wars. Furthermore arbitral tribunals are frequently set up ad hoc for particular disputes. The International Law Commission has devised Model Rules on Arbitral Procedure. ${ }^{16}$ Over the years a great many international arbitrations have been conducted and there exists a great quantity of international law concerning them. The extraordinary growth in international trade in the last 50 years has caused a big increase in international commercial arbitrations. The United Nations Commission on International Trade Law has made refining and developing the rules for international commercial arbitration an important focus. ${ }^{17}$

12 Vienna Convention on the Law of Treaties, ibid at art 66 and Annex.

13 Vienna Convention for the Protection of the Ozone Layer 26 ILM 1529 (opened for signature 22 March 1985, entered into force 22 September 1988), art 11(5).

14 United Nations Convention on the Law of the Sea 21 ILM 1261 (opened for signature 10 December 1982, entered into force 14 November 1994).

15 United Nations Model Rules for the Conciliation of Disputes GA Res 50/50, A/Res/50/50 (1996).

16 Model Rules of Arbitral Procedure with general commentary in Report of the Commission to the General Assembly [1958] vol 2 YILC 78 at [22].

17 United Nations Commission on International Trade Law "International Commercial Arbitration \& Conciliation" < www.uncitral.org>. 
While there is much literature upon the consensual nature of the jurisdiction of the International Court of Justice there is something of an increasing tendency towards compulsory provisions in treaties providing for dispute settlement. The World Trade Organisation has a sophisticated mechanism that New Zealand used successfully in the dispute over the export of New Zealand apples to Australia. ${ }^{18}$ The UNCLOS also has important elements of compulsory jurisdiction in order to provide effective dispute settlement mechanisms. ${ }^{19}$ In the case of the UNCLOS, the provisions were inserted, it seems, to avoid unreasonable unilateral interpretation of the Treaty. Such interpretations of customary international law norms are not infrequently made by nations and this was the mischief aimed at. Article 286 of the UNCLOS (with some exceptions specified in arts 297 and 298) states that in any dispute concerning the "interpretation or application of this Convention", where the parties have not agreed upon a method of dispute settlement, the dispute shall be submitted "at the request of any party to the Court or Tribunal having jurisdiction under this." Few means of escape here. Perhaps this trend will grow.

At the apex of the dispute settlement pyramid sits the International Court of Justice. ${ }^{20}$ Bear in mind that 66 States, including New Zealand, do now accept the compulsory jurisdiction of the Court under the so-called optional clause of the Statute of the International Court of Justice. ${ }^{21}$ Nevertheless, essentially the jurisdiction of the Court is consensual. States are not obliged to accept the compulsory jurisdiction of the Court and most do not. But many accept it for a particular dispute by special agreement. Nonetheless "nearly 250 treaties currently in force provide for resolution of disputes by the International Court". ${ }^{22}$ And the Court also has jurisdiction to issue advisory opinions when requested by the United Nations Security Council or the General Assembly. ${ }^{23}$ The General Assembly is empowered to authorise other United Nations organs and agencies to seek advisory opinions under art 96 of the Charter.

As is well known, New Zealand and Australia argued strongly at the time of the foundation of the United Nations that the Court should have compulsory jurisdiction in respect of all member

18 Australia - Measures Affecting the Importation of Apples from New Zealand WT/DS367/AB/R, 17 December 2010 (Report of the Appellate Body).

19 United Nations Convention on the Law of the Sea, above n 14, arts 286-295. See also Louis B Sohn "Settlement of Disputes Arising out of the Law of the Sea Conversation" (1975) 12 San Diego L Rev 495.

20 Shabtai Rosenne The Law and Practice of the International Court of Justice 1920-2005 (4th ed, Martinus Nijhoft, Leiden, 2006).

21 This number from Cour Internationale de Justice/International Court of Justice "Declarations Recognizing the Jurisdiction of the Court as Compulsory" <www.icj-cij.org>.

22 Louis Henkin and others International Law: Cases and Materials (West Publishing Co, St Paul, 1993) at 809, citing United Nations International Court of Justice Yearbook (Martinus Nijhoff, Dordrecht, 1985) issue 39.

23 Statute of the International Court of Justice, arts 65-68. 
States, but were defeated by the great powers. ${ }^{24}$ Russia and China have never accepted the jurisdiction of the Court either under the optional clause or by special agreement. The United States terminated its acceptance of the compulsory jurisdiction effective 1986 in the aftermath of a decision of the Court in a case Nicaragua brought against the United States for military and paramilitary activities, particularly the laying of mines in Nicaraguan ports. ${ }^{25}$ At the time the United States noted only 47 countries accepted the compulsory jurisdiction. France terminated its acceptance of the compulsory jurisdiction in the wake of the Nuclear Tests Case. The United Kingdom is the only permanent member of the Security Council that accepts the compulsory jurisdiction of the Court. There are some interesting legal intricacies about the optional clause contained in art 36 of the Statute of the International Court of Justice although they cannot be explored here. ${ }^{26}$

24 Department of External Affairs Report of the New Zealand Delegation to the United Nations Conference on International Organization (Department of External Affairs, No 11, 1945) at 103004.

25 Military and Paramilitary Activities in and against Nicaragua (Nicaragua $v$ United States of America) (Jurisdiction) [1984] ICJ Rep 392; Military and Paramilitary Activities in and against Nicaragua (Nicaragua $v$ United States) (Merits) [1986] ICJ Rep 14; Abraham D Sofaer "Legal Adviser Sofaer Statement Dec 4 1985" statement made to Senate Foreign Relations Committee as reported in (1986) 86 Department of State Bulletin (No 2106) 67.

26 The text of art 36 reads:

1. The jurisdiction of the Court comprises all cases which the parties refer to it and all matters specially provided for in the Charter of the United Nations or in treaties and conventions in force.

2. The states parties to the present Statute may at any time declare that they recognize as compulsory ipso facto and without special agreement, in relation to any other state accepting the same obligation, the jurisdiction of the Court in all legal disputes concerning:

a. the interpretation of a treaty;

b. any question of international law;

c. the existence of any fact which, if established, would constitute a breach of an international obligation;

d. the nature or extent of the reparation to be made for the breach of an international obligation.

3. The declarations referred to above may be made unconditionally or on condition of reciprocity on the part of several or certain states, or for a certain time.

4. Such declarations shall be deposited with the Secretary-General of the United Nations, who shall transmit copies thereof to the parties to the Statute and to the parties and the Registrar of the Court.

5. Declarations made under Article 36 of the Statute of the Permanent Court of International Justice and which are still in force shall be deemed, as between the parties to the present Statute, to be acceptances of the compulsory jurisdiction of the International Court of Justice for the period which they still have to run and in accordance with their terms.

6. In the event of a dispute as to whether the Court has jurisdiction, the matter shall be settled by the decision of the Court. 
The important feature of the optional clause is that it operates under a theory of reciprocity. So the Court has jurisdiction only to the extent that both parties have accepted a common commitment. That is determined at the time the Court is seized of a case. ${ }^{27}$

In light of this situation it is hard to disagree with the assessment of Professor Hans Morgenthau, that arch-realist in the study of politics among nations. In a book published at a time I was privileged to be his student at the University of Chicago he said, "international adjudication is unable to impose effective restraints upon the struggle for power on the international scene." ${ }^{28}$ Furthermore, such an analysis would suggest the loose nature of the obligations in art 33 of the Charter do not hamper nations a great deal in keeping alive disputes they want to keep alive by one means or another. The incentives to solve the dispute come from elsewhere. To solve disputes requires above all political will, whether the problem is bilateral or multilateral. Political will in the final analysis is the province of ministers rather than diplomats. In democracies many of the limitations upon dispute settlement flow from views of citizens. Where these are inflamed settlement will be more difficult. Where opinion is indifferent resolution will be easier.

I learned early in my career that in international matters law is one thing but not always the most important thing. I studied international law under Dr George Barton at the Victoria University of Wellington. All law students did in those days. It was a compulsory course. That made sense to me and it still does, even more now in a globalised world. I had done a Bachelor of Arts in political science and I knew from international politics courses that international affairs did not revolve around the law. I often said so in George Barton's class. This attitude was reinforced when I arrived at the University of Chicago and took international law from the redoubtable Professor Soia Mentschikoff who was married to Karl Llewellyn; it was hard to avoid the prevailing American scepticism about international law. Across the Midway in Professor Morgenthau's graduate courses on international politics, of which I took two, the sentiment was expressed even more strongly. Part of this was the context of being in the United States. Citizens of large and powerful nations tend more to the view that might is right. People from smaller nations tend to think the law should protect the small and the weak.

Shortly afterwards in 1969 I arrived at the University of Iowa College of Law where the curriculum was in ferment. It was very exciting. The overarching theory was that law should be studied in the social, economic and political context in which it functions. Two elements were particularly controversial. A new course entitled "Conflict Resolution" was designed. It was described as a course which: ${ }^{29}$

27 E Brown Weiss "Reciprocity and the Optional Clause" in Lori F Damrosch (ed) The International Court of Justice at a Crossroads (Transnational Publishers, Dobbs Ferry (New York), 1987) at 82.

28 Hans J Morgenthau Politics Among Nations (Alfred A Knopf, New York, 1967) at 224.

29 College of Law, The University of Iowa Official Calendar 1970-71 (Iowa City, Iowa, 1970) at 37. 
... studies the process of resolving disputes through consideration of conflicts ranging from the interpersonal to the international. The course investigates the sources of conflicts, examines the techniques of resolution (both within and without the legal system as commonly understood) and considers the application of those techniques in new contexts, and evaluates the societal consequences which have resulted or can result from the use of the options available.

The bold aim was to force students to think outside the context of law and courts to social dynamics underlying the law. There was a lot of student resistance to it and the Iowa bar did not like the curriculum either. The topics dealt with included negotiation, settlements, plea bargaining, mediation, conciliation, community conflicts and administrative tribunals. There was a lot of social science material in the course materials. This was in the first semester of law school. In the second semester students studied international law as a compulsory first year course. The prescription for this course set out its aims: ${ }^{30}$

\footnotetext{
Examines the past present and future role of law in promoting world public order among a broad spectrum of participants (national states, international governmental organisations, private associations and individual human beings) who are engaged in a wide variety of pursuits across national and other territorial boundaries The course introduces the student to problems of authority and notions of jurisprudence in a legal system that usually operates in the absences of a 'police force' as commonly understood.
}

I taught both these courses. It was a fascinating experience. Teaching students how to do these things proved not to be easy. Teaching legal principle and reading cases is much easier. Yet lawyers have to be encouraged to search for new techniques of resolving conflict. Lawyers in practice spend much of their time negotiating, mediating and finding means of conciliation. They need to know how to do it. This curriculum was in my view exactly right. These skills are not doctrinal. In many ways that is what diplomats do - dispute resolution. Traditionally in the world of diplomacy you reached an accommodation or you had a war. The purpose of diplomacy is to promote a nation's national interest by peaceful means. The problem is that whether it is by the application of the law by adjudication or use of the wider techniques of dispute resolution and diplomacy some disputes stubbornly resist resolution for political reasons. If there is an interest in curing that resistance it is to the behaviour of political decision makers we must look.

In my own experience both in the International Whaling Commission and the Gaza Flotilla Panel the books I found most useful were practical books from the Harvard Negotiation Project: Roger Fisher's International Conflict for Beginners and Roger Fisher and William Ury's Getting to Yes. ${ }^{31}$ Whatever techniques are used, however, it must be understood that not all disputes can be

30 Ibid at 38.

31 Roger Fisher International Conflict for Beginners (Harper \& Row, New York, 1970); Roger Fisher and William Ury Getting to Yes: Negotiating Agreement Without Giving In (Penguin Books, New York, 1991). 
solved or at least not at the time the attempt is made. The effluxion of time seems the most emollient factor - passions cool and other priorities take over. A dispute has to be ripe for resolution at the time of the attempted resolution in the sense that there are sufficient political incentives on all the countries involved to reach a compromised outcome. In some of the matters with which I have been involved I have seen great unwillingness to compromise; I hope it is not a growing trend.

The United Nations essentially is a diplomatic organisation. Its methods are the methods of diplomacy. As Judge Rosalyn Higgins has said "[t]he United Nations is a key institution in the endeavour to avoid, contain, and resolve disputes." 32 As this survey has made clear, the Charter offers many dispute settlement menus that can be used with creativity where there is a desire to settle a dispute on the part of those engaged in it. The increasing use of United Nations panels to find facts is itself a fresh contribution to the techniques of dispute settlement as will become evident in the discussion of the Gaza Flotilla Panel. Most disputes are no doubt dealt with outside the ambit of the United Nations. Yet the methods remain identical whether in bilateral or multilateral contexts. In the participant observations that follow both types of dispute are covered.

\section{THE NUCLEAR TESTS CASES}

New Zealand's nuclear free policy created apprehension among important nations that had been our traditional friends. In fact the policy led to significant international disputes. The dispute with the United States over ANZUS was a significant development in New Zealand's evolution of an independent foreign policy. It altered the relationship New Zealand had with the United States and impaired it. While the relationship is now largely restored it is not the same as it was. The disputes with France involved two trips to the International Court of Justice over atmospheric and then underground nuclear testing. There was also the Rainbow Warrior affair in which a ship was sunk in Auckland harbour by agents of the French secret service, the Direction Générale de la Sécurité Extérieure (DGSE).

The common thread running through the disputes was the anti-nuclear sentiment that became strongly established over a long period in the minds of the New Zealand public. The dispute with France was notable for the lengthy period that it endured in one form or another from the early 1970s until the 1990s. French testing in the south west Pacific had a profound effect upon public opinion in the region and was the catalyst for the anti-nuclear movement within both Australia and New Zealand.

I recall teaching at the University of Virginia Law School in 1973 when New Zealand sent a frigate up to the Mururoa Atoll in French Polynesia to protest France's atmospheric nuclear testing there. Professor Emerson G Spies greeted me in the Faculty common room for morning tea with the query: "Is your Government for real?" Of course the Labour Government of the day was serious. In

32 Rosalyn Higgins Problems and Process: International Law and How We Use It (Clarendon Press, Oxford, 1995) at 169. 
May 1973 it had commenced proceedings in the International Court of Justice, as did Australia, against the French Government seeking an end to their atmospheric testing of nuclear weapons in French Polynesia.

Australia and New Zealand argued that the French nuclear testing programme was contrary to international law. New Zealand argued that the French Government tests in the south Pacific region that gave rise to radioactive fallout constituted a violation of New Zealand's rights. The Court gave interim relief. ${ }^{33}$ It indicated that pending further stays of the case France should cease testing. In December 1974 the Court held, following the issuance of a media release by the French Government, that since France had promised not to test nuclear weapons in the atmosphere and was bound by its own promise to that effect the proceedings could be terminated as they no longer had any purpose and the Court did not need to decide them. ${ }^{34}$ France moved to terminate its acceptance of the compulsory jurisdiction of the International Court of Justice under the optional clause as it was entitled to do. It resumed underground nuclear testing at the same location.

In 1995 this case was resumed by New Zealand at the International Court of Justice. New Zealand filed with the Court a Request for an Examination of the Situation in light of the 1974 judgment because France announced it would conduct a final series of eight tests of nuclear weapons in the south Pacific starting in September 1995. ${ }^{35}$ The resumed case concerned underground testing, not the atmospheric testing that the French had ceased that had the effect of rendering the original case moot. The Prime Minister, the Rt Hon Jim Bolger, said: ${ }^{36}$

It was New Zealand's view that any resumption of nuclear testing in the South Pacific was totally unacceptable, and contrary to the legal, environmental, and political developments of the last two decades. The Government looked, therefore, to every possible avenue to challenge the testing, including legal means.

I was appointed by the New Zealand Government as the ad hoc judge on the Court for the case. I was signed into office by Sir Garfield Barwick, the former Chief Justice of Australia, who had been the ad hoc judge for both Australia and New Zealand in 1974. Australia could not resume its case because its pleadings in the original case were more restrictive than the "venting" language in the New Zealand pleading. While the case was a big ask, some members of the Court did not want to hear the case and I had to be firm and downright at the judicial conferences to say that New

33 Nuclear Test Case (New Zealand v France) (Provisional Measures) [1973] ICJ Rep 135 at 138.

34 Nuclear Test Case (New Zealand v France) (Jurisdiction) [1974] ICJ Rep 457.

35 Request for an Examination of the Situation in Accordance with Paragraph 63 of the Court's Judgment of 20 December 1974 in the Nuclear Tests Case (New Zealand v France) Case [1995] ICJ Rep 288.

36 Jim Bolger "Foreword" in Ministry of Foreign Affairs and Trade New Zealand Ministry of Foreign Affairs \& Trade New Zealand at the International Court of Justice: French Nuclear Testing in the Pacific (Ministry of Foreign Affairs and Trade, 1995) at 7. 
Zealand expected to be heard. France made big efforts to ensure the case was not heard. And with the Court being in the Netherlands proximate to France, French influence at The Hague was ever present. The expedience with which the matter had been approached to begin with drew criticism from Judge Stephen Schwebel. He refuted the notion that there was no case, there was no room for appointment of agents or an ad hoc judge and the Court could not have oral hearings. He concluded rather delightfully: ${ }^{37}$

Whatever the reservations expressed, it is plain that when 15 judges gathered in their robes in the Great

Hall of Justice of the Peace Palace, and when Judge ad hoc Sir Geoffrey Palmer took his oath of office,

the Members of the Court did not meet, Pirandello style, in search of a courtroom or a case, but

conducted an oral hearing on a phase of a case.

I found it an unsatisfactory professional experience. There seemed to be an acute sensitivity to the political limits of the Court's authority. Furthermore, I felt that many of the judges had political factors weighing heavily on their mind and did not want to upset powerful nations who were permanent members of the Security Council over the nuclear issue. The same influences were at work a little later in 1996 when the Court delivered the Nuclear Weapons Advisory Opinion. ${ }^{38}$ The Court on that occasion spoke in strong condemnation of the use of nuclear weapons but stopped short of holding them to be illegal in all circumstances. In extreme circumstances involving the very survival of the State, using them may be lawful, the Court held. The fact that the five permanent members of the Security Council always have a judge on the Court and that they are all nuclear weapons States did not add to my sense of fairness. It needs to be recognised, however, that the permanent five are on the Court because they are elected there because of the requirement that each judge needs to have a majority on the Security Council. With mutual support the permanent five can ensure five votes of the necessary eight.

This was not a court that operated in the same way as courts to which I was accustomed in New Zealand, the United Kingdom and the United States. It was partly because a majority of the judges were not common lawyers but lawyers trained in the civil law tradition that is based on Roman law where there is a code. The different approaches influence the attitude to international law even though the law is supposed to be the same whether one is a product of the civil law tradition or a common lawyer. But I came away from this unusual legal experience with the conviction that the judges at The Hague needed a strong dose of judicial independence as I understood that principle. It was a disappointment.

The fact that France had withdrawn its acceptance of the compulsory jurisdiction under the optional clause over the earlier case in 1974 was also a factor in the 1995 resumption of the case. On the previous occasion France had not even appeared at the Court to argue the substantive case. This

37 Declaration of Vice-President Scwebel in Nuclear Tests Case (New Zealand v France), above n 35, at 309.

38 Legality of the Threat or Use of Nuclear Weapons (Advisory Opinion) [1996] ICJ Rep 66. 
time they were present unrobed, with the exception of Sir Arthur Watts, and made legal arguments. Yet I saw first-hand that justice according to law was not an easy ingredient to obtain in a court where many of the judges had been diplomats and legal advisers to Foreign Offices. International law is more influenced by political factors than law administered in domestic jurisdictions with which I am familiar. Of course it would have been a very brave court that would have decided that the tests at Mururoa were unlawful. That was obvious enough. But I was convinced on the grounds of the potential damage to the environment that probably existed. Judge Christopher Weeramantry wrote a wonderful dissenting opinion of permanent juridical importance outlining the arguments. ${ }^{39} \mathrm{I}$ also wrote a dissenting judgment mainly concerned with the development of international environmental law and the principles that applied to underground French nuclear testing. ${ }^{40}$

New Zealand lost its application to reopen the case by 12 votes to three. Despite the result, the purposes of the New Zealand Government were well served by the case in their view. It brought political pressure to bear on France on the nuclear issue. The Prime Minister, Mr Bolger, said after it was over the Government remained satisfied with the decision to bring the case. "The case received great attention internationally and this without doubt added to the pressure on France to cease testing." ${ }^{41}$ Tests ceased in February 1996.

All of this is not to suggest the Court is not useful. Quite the contrary: I think the International Court of Justice as a principal organ of the United Nations is an essential ingredient of dispute settlement. But I thought then and I still think it needs reform. While I will not develop the case for change that I have advocated elsewhere, in short I think: the Court is too Eurocentric; the method of electing the judges should be changed to cut out political and representational issues; judges should not be permitted to serve for a second term; they should dispose of their cases more quickly; ad hoc judges should be abolished and where a sitting judge comes from a nation before the Court that judge should be disqualified; and the Court should have nine not fifteen judges. ${ }^{42}$ Furthermore, much greater effort should be made to codify international law so that nations can understand better the norms to which they are subject.

It may seem strange after such an experience that I believe compulsory jurisdiction for the Court is to be encouraged and needs to be developed and argued for by such nations as New Zealand who must put their trust in international law as much as possible because they are not powerful. A small

39 Dissenting Opinion by Judge Weeramantry, ibid at 317.

40 Dissenting Opinion by Judge ad hoc Sir Geoffrey Palmer, ibid at 381.

41 Jim Bolger "Foreword", above n 36.

42 Geoffrey Palmer "International Law and Reform of the International Court of Justice" in Antony Anghie and Gary Sturgess (eds) Legal Visions of the 21st Century: Essays in Honour of Judge Christopher Weeramantry (Kulwer International, The Hague, 1998) at 579. It should be noted that the number of judges in the Court remains the same as in 1945 when there were only 51 United Nations member States. My suggestion is based on the need to avoid representational factors. 
nation has a better chance of having international law applied fairly and in accordance with neutral principles if it occurs via adjudication by an independent judge. The military or economic strength of one nation compared with another should not be the source of authority. That is the law of the jungle. The rule of law at an international level is capable of conferring the same benefits to the international community as it does in municipal law. But it needs to be given the authority to do so. Reason, justice and fairness have a better chance with compulsory jurisdiction. ${ }^{43}$

As has already been made clear after the 1974 case underground nuclear testing continued to attract protest and was a continuing cause of irritation especially considering the environmental pollution it was thought to be causing. By 1985 that led the 15 members of the South Pacific Forum, as it was then known, to negotiate the South Pacific Nuclear Free Zone Treaty. ${ }^{44}$ The Treaty establishes a legal regime to keep the South Pacific nuclear free. Securing such a consensus among Pacific Island nations was not a difficult thing. They felt threatened by the testing. Over time the abhorrence felt by the population of New Zealand for nuclear weapons inevitably came to be reflected in policy terms by both main political parties in New Zealand. It endures at the time of writing.

So far as the Americans are concerned, ship visits from the Seventh Fleet attracted protest on the grounds of both nuclear propulsion and the possible presence of nuclear weapons in New Zealand. This was made worse by the fact that ship visits seemed to be organised by the Muldoon Government in a manner that would divide the community and occur close to general elections. Such was the background to the ANZUS dispute, the International Court of Justice case involving underground testing, and the Rainbow Warrior.

\section{THE DISPUTE WITH THE UNITED STATES}

The 1951 ANZUS Treaty between the United States, Australia and New Zealand was signed on 8 September 1951 just days before the Peace Treaty ending the Second World War with Japan was concluded. ${ }^{45}$ The obligations of ANZUS are of a loose and general character; it is not an elaborate treaty arrangement in the nature of the NATO, for example. It comprises a simple text of 11 spare articles. The core of it is contained in arts II and IV.

Article II of the ANZUS Treaty is legally significant and provides:

43 A most interesting analysis of adjudication is contained in Richard B Bilder "International Settlement and the role of International Adjudication" in Lori F Damrosch The International Court of Justice at a Crossroads, above n 27, at 155.

44 South Pacific Nuclear Free Zone Treaty 24 ILM 1442 (opened for signature 6 August 1985, entered into force 11 December 1986).

45 Security Treaty between Australia, New Zealand and the United States of America [1952] NZTS 8 (signed 1 September 1951, entered into force 29 April 1952). 
In order more effectively to achieve the objective of this Treaty the Parties separately and jointly by means of continuous and effective self-help and mutual aid will maintain and develop their individual and collective capacity to resist armed attack.

Article IV:

Each Party recognizes that an armed attack in the Pacific Area on any of the Parties would be dangerous to its own peace and safety and declares it would act to meet the common danger in accordance with its constitutional processes.

The Treaty also establishes an ANZUS Council.

The Fourth Labour Government was elected in 1984 on a policy pledge to declare New Zealand nuclear free and work actively for a nuclear weapons free zone in the south Pacific. Labour Party conferences had for years been passing resolutions to ban nuclear-powered and nuclear armed ships from New Zealand ports. The policy may have required a review of ANZUS but the party leadership was not prepared to campaign on a policy to leave the alliance. In fact David Lange in Opposition called for a change to the nuclear powered aspect of the policy. The dispute with the Americans revolved around whether New Zealand could have a nuclear free policy and remain in ANZUS. There was an enormous amount of diplomatic and political manoeuvring over these issues that are beyond the scope of this paper. ${ }^{46}$

The precise nature of the legal obligation under the ANZUS Treaty was problematic because of the loose and general manner in which the language of obligation was framed. ${ }^{47}$ The Treaty itself imposes no obligations to accept ship visits. New Zealand did not see them as central to the dispute. On the other hand, it could be said that such visits may assist in maintaining the three nations'

46 Not surprisingly quite an extensive literature has been written over the origins and execution of the antinuclear policy, and it has contentious elements: Malcolm Templeton Standing Upright Here: New Zealand in the Nuclear Age 1945-1990 (Victoria University Press in association with the New Zealand Institute of International Affairs, Wellington, 2006); David Lange Nuclear Free: The New Zealand Way (Penguin Books, Auckland, 1990); David Lange My Life (Viking, Auckland, 2005); Michael Bassett Working with David: Inside the Lange Cabinet (Hodder Moa, Auckland, 2008); Margaret Pope At the Turning Point: My Political Life with David Lange (AM Publishing New Zealand for Jonathan Hudson \& Associates, Auckland, 2011); Ewan Jamieson Friend or Ally, New Zealand at Odds with its Past (Brassey's Australia, Sydney, 1990); Raymond Richards Palmer - the Parliamentary Years (University of Canterbury Press, Christchurch, 2010) at 11-30; Geoffrey Palmer "Living History Interview" (1991) 1 Transnatl L \& Contemp Probs 241; Margaret Clark (ed) For the Record - Lange and the Fourth Labour Government (Dunmore Publishing, Wellington, 2005). In particular contributions of relevance to what is said here in the last mentioned book are the contributions of John Henderson at 136, Merwyn Norrish at 150, and Gerald Hensley at 129. It will be appreciated that in this article I am not concentrating on the political aspects but on the dispute resolution angle.

47 JG Starke The Anzus Treaty Alliance (Melbourne University Press, Melbourne, 1965) at 103 makes the observation in relation to art II: "Notwithstanding that the obligations under the article are of a weighty nature, they are not reducible to specific terms". 
"individual and collective capacity to resist armed attack". ${ }^{48}$ Nevertheless, joint exercises could be held without port visits and such visits did not seem to be required for the operations of the United States to be effective.

For the Americans, however, the obligations to accept port visits seemed to be an inherent obligation in any treaty of alliance. They argued that such visits were essential to maintaining the three nations' individual and collective capacity to resist armed attack. It was essential to the continuing effectiveness of the alliance. They showed no willingness to allow New Zealand any room for its anti-nuclear policy. The American interpretation of its obligations seemed to be that New Zealand was required to admit to its ports without hesitation all ships of the United States Navy. The New Zealand Government thought that it was a reasonable position for a small allied State to take, in a region where there was no need for the deployment of nuclear weapons, to request that its allies not deploy nuclear weapons in ships coming to its ports.

It is worth pausing to remember the context in which these decisions were taking place. The Cold War was coming to an end, as we now know. The Americans may have sensed they were getting the upper hand and for New Zealand to raise objections to nuclear weapons may have been seen by them as the beginning of a slippery slope that could not be countenanced at that time.

At stake here for the Americans was their 'neither confirm nor deny' policy. That is to say the United States would neither confirm nor deny the presence of nuclear weapons upon its ships and expected strict conformity from its allies in respect to that policy. New Zealand did not see its policy as contrary to ANZUS. The United States did. So did the Australians because the Australian Government was embarrassed that an anti-nuclear sentiment shared by the Australian Labor Party would have more force in New Zealand than in Australia. Prime Minister Hawke made it clear that Australia could not accept that the alliance could have a different meaning and different obligations for different members. ${ }^{49}$

There were intricate efforts made to settle the dispute in particular by admitting a ship that New Zealand would be happy with. When the USS Buchanan ship was turned down by the Government in 1985 it became clear there was no easy way of resolving the dispute. The United States had wide global responsibilities including in Japan where there were particular sensitivities on nuclear issues for obvious reasons. In fact nuclear weapons went into Japan on American ships but the Japanese Government found that compatible with its anti-nuclear stance.

Under the Treaty the principal obligation on the allies apart from the responsibilities in the event of aggression in the South Pacific region is to work together in the defence field. New Zealand made it clear that it was prepared to do that. The single restriction was to reserve the right to say 'no' to

48 Security Treaty between Australia, New Zealand and the United States, above n 45, at art II.

49 David Lange Nuclear Free, above n 46, at 83. 
vessels that New Zealand judged to be likely to be carrying nuclear weapons. New Zealand did not seek to challenge the 'neither confirm nor deny' policy of the United States. It would make its own judgment based on the advice of its own military.

On matters of general international law relating to this dispute there was no disagreement between the United States and New Zealand. Both accepted that under the law of the sea the coastal States has the sovereign right to determine what foreign warships, if any, may enter its internal waters and on what conditions. The issue that divided the United States and New Zealand was the simple question of the extent to which the alliance commitments could be interpreted as permitting one party a measure of freedom in relation to nuclear weapons.

As with all disputes of this kind there were intensive diplomatic exchanges over a period of several years from January 1985 until August 1986. My own involvement with this tended to be episodic depending upon whether David Lange was in the country; he often was not since he was Minister of Foreign Affairs in addition to being Prime Minister. There were three main periods of involvement. The first was the decision on the USS Buchanan when David was incommunicado in Tokelau when some important developments took place in January 1985. There had been extensive discussions between officials of both countries to identify a ship that could come into a New Zealand port where New Zealand advisers would be comfortable that it could pass the test of the policy. Unfortunately I had not been briefed on these discussions although I knew David was working on the issue. The second was when I went to Washington as a result of a Cabinet decision to see at a late stage if a way through the impasse could be found in September 1985. I was also directly involved in discussions with the British in London in July 1986.

In retrospect, the decision to turn down the visit of the USS Buchanan was the turning point in the dispute. The vessel had been carefully selected to ensure that it would be acceptable to New Zealand in discussions between officials from both sides behind the scenes. It was not going to be carrying nuclear weapons. The request was made shortly before Christmas but a great media fuss erupted over the request in January when David Lange was visiting the Tokelau Islands. He left on that trip without briefing me on what was going on and when the story broke it was not possible to communicate with him. With public statements being made in Australia I had to quieten things down and made some forthright public statements reaffirming the policy. There was a political uproar. There was a lot of pressure from Australia. A letter from the Australian Prime Minister, Mr Hawke, had been leaked. There were leaks in Washington about the fact that a request had been made for a ship visit. A letter from the American Secretary of State had been leaked. The Opposition was attacking the Government. The New Zealand Executive of the Labour Party passed a resolution requiring the policy to be upheld. Marginal seat MPs were nervous we would buckle. Jim Anderton threatened to leave the party unless the policy was implemented.

I typed myself an analysis of the situation and sent it to David Lange by asking his press secretary Ross Vintiner to take it to him and meet the ship from the Tokelaus in Samoa. The prime advice I gave him was that it all depended on how strong the evidence was as to whether the ship 
could come in. And it depended on the strength of the case we could develop publicly that the ship was not carrying nuclear weapons. ${ }^{50}$ By the time the Cabinet met, I had been able to read and analyse the official advice I had sent to David Lange. The critical document was the memorandum from Air Marshal Jamieson, the New Zealand Chief of Defence Staff on the particular vessel. I construed it carefully and reached the conclusion that the position was not sufficiently clear. It seemed to me there needed to be convincing clarity from the New Zealand point of view about whether a vessel carried nuclear weapons, a standard of proof that approached the criminal standard of beyond a reasonable doubt rather than the civil standard judged on the balance of probabilities. I was not judging the context but the evidence. The possibility of Anti-Submarine Rocket (ASROC) missiles was particularly in my mind. I summarised my views to the Cabinet when it met but before David was present. David was late arriving back from Tokelau to the Cabinet on the following Monday. There had been a short discussion of the issue by then and when he came the matter did not detain Cabinet much longer. There was no long or contentious discussion. The ship was turned down although the communication to the Americans and public announcement took some time. The Caucus was very content with the decision.

It needs to be recorded that the Americans felt seriously let down by the decision on the USS Buchanan. They felt they had an understanding with David about how the ship visit would be managed. Merwyn Norrish, then the Secretary of Foreign Affairs, was present with David at the meeting in Wellington before the Government had changed. His published account of the meeting squares with David's that no assurance was given that the Party's policy would be changed on nuclear weapons. Whatever the understandings on each side were, there can be little doubt that the Americans nursed a sense of grievance over how the matter was handled by New Zealand. As to the background of understandings on the USS Buchanan itself they were closely held and the Cabinet as a whole was unaware of the detail and so was I.

There ensued protracted diplomatic discussions with the Americans and it was decided that I should visit Washington to try and see whether an accommodation could be reached. The reason was that I knew well the Deputy Secretary of State Kenneth Dam. He had taught me international trade law at the University of Chicago Law School at a time when George Shultz was Dean of the Business School. I had stayed at his home in Chicago when I was a law professor at the University of Iowa. I felt this personal contact would help. In the end it did not because Ken had left State to become a Vice-President of IBM not long before I arrived.

It was necessary to discuss with the Americans the draft legislation that had been prepared to implement the South Pacific Forum Nuclear Free Zone Treaty. The New Zealand policy in relation to ship visits was to be embedded in the Bill and I had discussions with Colin Keating, the head of the Legal Division of the Ministry of Foreign Affairs about how that should be approached in legal

50 Memorandum from Geoffrey Palmer (Deputy Prime Minister) to David Lange (Prime Minister) regarding the USS Buchanan (27 January 1985). 
terms. He had been in charge of drafting the Bill in Foreign Affairs. He came with me on the team that went to Washington. I wanted to explore with the Americans whether they could accept that the New Zealand Government could make judgments on whether a ship could come in and that it was in conformity with the anti-nuclear policy without asking the Americans for information about whether the ship was nuclear armed.

Dealing with the United States on issues such as this is not easy because it involves many agencies of a massive Government: the State Department, the Department of Defence, the United States Navy, the National Security Council, the Congress and the President through the White House. The nuances of view on the issues with New Zealand varied and a lot of diplomatic energy had to be exerted to explore those views. In Washington in September 1985 I met separately with the Secretary of State George Shultz, the Defence Secretary Caspar Weinberger and other officials including Rich Armitage and Paul Wolfowitz, Assistant Secretaries of Defence and State respectively. There was no interest on their part in discussing the legislation.

What remains in my mind most is the clear articulation of the problem from the American point of view by George Schultz, the Secretary of State, who said he knew the approach we were advocating would not work. It was a sophisticated and nuanced idea that involved a necessary amount of ambiguity on both sides. It also involved an element of trust on both sides and a high level of political robustness in New Zealand to be able to resist the pressure for absolute certainty. He knew New Zealanders from his experience in the Second World War. He said ships could not come into New Zealand ports with nuclear weapons on board and that New Zealanders would look the other way. (This is what occurred in Japan.) It was also clear that the idea being advanced had been tried with the USS Buchanan and it had not worked then because of the ambiguity. Shultz therefore was not prepared to accept the approach that New Zealand could make its own mind up about the capability of the ship being assessed. I left Washington convinced that no further diplomatic negotiations could find a way through, and although further efforts were tried they did not succeed.

Despite my view, a huge effort was made by New Zealand in the next 10 months before the final rupture came. The aim was to continue to explore whether language on ports visits in the Bill could be made to work. The United Kingdom was attempting to be helpful. I conducted discussions with British Ministers in July 1986 and I had to say to Baroness Young that there seemed no point in reaching a compromise with the British if the Americans would not accept it.

In the end New Zealand and the United States arrived at a mutual understanding that the issue could not be solved and the negotiations were put in abeyance in 1986. Shultz at a media conference in California in 1986 put it this way: ${ }^{51}$

51 George Shultz, United States Secretary of State, Press Conference (San Francisco, California, 11 August 1986). 
[W] tried hard to see if there isn't some way that this could be worked through, but there are certain hard realities that you have to face, and I think in the end, New Zealand chose, as it had a right to do, basically to withdraw itself from the alliance by denying port access we are sorry about that. I miss New Zealand, and as I said after my meeting with Prime Minister Lange in Manila only a few weeks ago, we part as friends.

From the New Zealand point of view this did not seem quite to be the case. There was intransigence on the part of the United States. I got the impression over time that the Americans felt if they exerted enough pressure, along with the Australians, New Zealand would buckle. The antinuclear sentiment in New Zealand was much stronger than in Australia and much stronger I believe than the Americans expected or understood. I tried to convey to the Americans the need to respect the imperative of our own democratic processes. The Government would fly in the face of the antinuclear sentiment at its peril. The fact that the policy did not change when the Government changed in 1990 would seem to add weight to that view.

The measures that were taken against New Zealand were not insignificant. The United States ceased to provide New Zealand with finished intelligence. Intelligence briefings would be stopped. Imagery intelligence would not be delivered. New Zealand would be excluded from intelligence conferences. Bilateral military exercises would be cancelled. Military secondments would stop. New Zealand was no longer treated as having the special relationship of a close ally for the purposes of military sales and commercial export licences for defence related equipment. ${ }^{52}$

The United States told New Zealand in September 1986 that it had suspended as between the United States and New Zealand the obligations of the ANZUS Treaty. It argued that New Zealand was in material breach of art II because its action effectively precluded the United States from carrying out its obligations to New Zealand. New Zealand rejected that legal view. After a vigorous exchange the legal issue was not pursued further by either side. New Zealand may have chosen to withdraw but legally it is doubtful that the United States had a right to suspend New Zealand from ANZUS.

Clearly although there were legal elements to this dispute, especially the proper interpretation of the Treaty, the matter was handled politically in the end because that suited both sides for their separate reasons. There was no question of adjudication, arbitration or even mediation. There were serious discussions over the issues with the Australians and the British. But in the end it was the attitude and approach of the Americans that was the critical factor. They forced New Zealand to choose and New Zealand chose. The fact that everything is different now in respect to 'neither confirm nor deny' has meant that the situation has moved towards New Zealand's position rather than away from it.

52 Malcolm Templeton Standing Upright Here, above n 46, at 421. 


\section{THE RAINBOW WARRIOR}

The dispute that arose out of the sinking of the Rainbow Warrior on 10 July 1985 while intrinsically fascinating was also a fertile field for the application of dispute settlement techniques. ${ }^{53}$ Of all the disputes dealt with in this paper it was the one that was the most completely resolved and put behind the nations involved, although it lasted a long time. My primary involvement with the dispute was not only as a member of Cabinet but also being the minister who gave the speech to the United Nations General Assembly raising the issue there on 24 September 1985 complaining that France as a nuclear weapon State "continues to test nuclear explosives against the manifest and long established wish of all the countries in the area that this activity should cease." ${ }^{54}$ I then went on to recite the events of the sinking, the death of one of the crewmen, a Dutch national and the arrest of the two French nationals charged with murder and arson. I pointed out that France had acknowledged that French secret service agents did indeed sink the ship acting under orders.

In New York I met with the French Foreign Minister, Dr Roland Dumas, and began negotiations about how to settle the dispute. We met twice in New York and officials continued the negotiations afterwards. On 4 November 1985 the French agents pleaded guilty to manslaughter and wilful damage; they were sentenced by the Chief Justice Sir Ronald Davison to 10 years imprisonment. ${ }^{55}$ It was obvious from the outset that the bombing of the ship constituted a very serious violation of international law for which France clearly had legal responsibility. It was clear that New Zealand was entitled to reparations for the wrong done and an apology and compensation for the considerable cost to which New Zealand had been put on account of the actions of France. It might have been possible to take the dispute to the International Court of Justice but for the fact that France had terminated its acceptance of the compulsory jurisdiction over the cases Australia and New Zealand brought over atmospheric testing in the Pacific in the 1970s. Unless France would voluntarily accept an arbitral tribunal or accept the jurisdiction of the International Court of Justice for this specific case there was no way to force an adjudication.

As matters developed such an adjudication would have been impossible in any event. There were wider political considerations that had to be weighed on both sides. New Zealand felt it could only agree to a settlement of its claim if Greenpeace was adequately compensated and the family of Mr Pereira, the dead crewman, was compensated. But as a matter of international law New Zealand

53 I have written about this event previously: Geoffrey Palmer "Settlement of International Disputes: the 'Rainbow Warrior' Affair" (1989) 15 CLB 585; Geoffrey Palmer "Adjudication, Politics and International Law" (2003) 17 Temple Intl \& Comp L J 523; Geoffrey Palmer "The Difficulties of Third-Party Adjudication for Political People" 97 Proceedings of the Annual Meeting (American Society of International Law) 289.

54 Geoffrey Palmer, Deputy Prime Minister "Address to the United Nations General Assembly" (1985) 35 New Zealand Foreign Affairs Review 21 at 23.

55 The full sentencing notes of the Chief Justice are reproduced at "Sentencing for manslaughter - pleas of guilty - mitigation of sentence for terrorist activities" (1986) 12 CLB 380. 
could not assert those claims. New Zealand was saying that it was a political imperative that decent arrangements be made for compensation for damage suffered in New Zealand but not by New Zealand. New Zealand was entitled only to assert claims suffered by New Zealand as a State.

France had a demand of the same kind. It wanted the return of the prisoners. It argued that their imprisonment in New Zealand was not justified because they had acted under military orders of the French Government. But New Zealand could not tolerate political interference by ministers with the New Zealand judicial process and it was not open to the Government to agree or even negotiate about the two prisoners while the cases were before the courts. As the Attorney-General I made this point crystal clear to France at the outset of the negotiations. Furthermore we made clear to France that under New Zealand law and international law the fact that the agents were acting under military orders did not exempt them from criminal responsibility under New Zealand law. 'Superior orders' was no more a defence under New Zealand law than it was under international criminal law.

What became known as 'release to freedom' was not acceptable to New Zealand but in the bilateral negotiations New Zealand made it clear we were ready to explore the possibilities of the prisoners serving out their sentences outside New Zealand. To which France pointed out there was no basis either in international law or in French law on which the two could serve out any portion of the New Zealand sentence in France. So France had a political imperative to get its people back even though they had no legal basis for their insistence. New Zealand was entitled to try and imprison people who committed criminal acts in its territory. New Zealand wanted to settle the dispute but not surrender the prisoners.

The politics were the central problem not the law. Reparation and an apology, to which New Zealand was entitled under international law, could be secured only by releasing the prisoners to France. While New Zealand had the legal power to do this it was not obliged to do so and the political heat from doing so would have been substantial. What looked good to France, the release of the prisoners, was not a matter to which they had a legal right and New Zealand would not agree. As negotiations bogged down the dispute widened. France threatened to question New Zealand exports to Europe, especially of butter. The imports to France of New Zealand sheep brains were held up. New Zealand lodged a complaint with the OECD and took steps under the GATT making it clear that any settlement would require the lifting of any trade restrictions imposed. ${ }^{56}$

So the issues that presented themselves for resolution were of many dimensions. They were:

- $\quad$ an apology and compensation from France for a violation of New Zealand's international law rights;

- compensation for Greenpeace and the family of the dead crewman;

56 These matters are all traversed at length in the Secretary-General's ruling, reprinted in Rainbow Warrior Case (New Zealand v France) (1987) 26 ILM 1346 and (1987) 74 ILR 256. 
- $\quad$ existing and future trade relationships between the two countries; and

- $\quad$ the fate of the two French agents imprisoned in New Zealand.

New Zealand also added a further element, having observed the severe political pressures in France, that any settlement should contain a procedure for binding adjudication in the event that there was a later dispute about the application or interpretation of the terms of the settlement. Things became bogged down and the Dutch Prime Minister offered to mediate.

As a result, France and New Zealand approached the Secretary-General of the United Nations Javier Perez de Cueller to assist. On 19 June 1986 it was announced simultaneously in both Paris and Wellington that both countries had agreed to refer all the problems between them over the Rainbow Warrior for a binding ruling. He was not asked to determine the law - on some vital questions there was none. Instead he was asked to produce a determination on every aspect of the affair that was both equitable and principled. Both sides submitted their written statements. And he produced a binding ruling.

Behind the scenes, however, most elements of the binding ruling had been secretly negotiated between New Zealand and France in Switzerland. The lead negotiator was Chris Beeby. The reasons were essentially two. First, domestic opinion in both countries was highly charged over the issue. A settlement negotiated bilaterally that did not carry the respected imprimateur of a third party could have increased the level of domestic criticisms for both Governments. Furthermore, if the elements are negotiated the two countries and their ministers keep control of the matter. Second, closed diplomacy works better for producing settlements of difficult issues. Megaphone diplomacy never helps even if it makes ministers feel better. Negotiations have to be in secret because if the media knows they are on there will be comments forced out of the participants. Such comments tend to inflame the dispute rather than lead to its resolution.

The Secretary-General did himself settle the amount of compensation to be paid by France to New Zealand - USD 7,000,000. The ruling as announced by the Secretary-General provided for: ${ }^{57}$

- $\quad$ an apology;

- compensation;

- transfer of the agents to a French military facility on an isolated island outside Europe for three years (Hao Atoll in French Polynesia). They should be prohibited from leaving for any reason. The New Zealand Government was to receive reports that the conditions were being implemented;

57 Ibid. 
- a French undertaking not to oppose continuing imports of butter to the United Kingdom and not impair the agreement on trade with the European Economic Community in mutton, lamb and goat meat;

- a binding arbitration procedure as part of the ruling in the event that disputes arose over the ruling; and

- an acknowledgement that compensation arrangements for Pereira's family and Greenpeace had been made.

Within two years the arbitration provisions had to be used by New Zealand because Major Alain Marfart was evacuated to France for medical reasons and not returned. Dominique Prieur was accompanied to Hao by her husband, became pregnant, and her father was dying so she was returned to France shortly before his death and never returned to Hao either. So in September 1988 an arbitral panel was set up. It was chaired by a former President of the International Court of Justice Dr Eduardo Jimenez de Arechage with Sir Kenneth Keith from New Zealand and M JeanDenis Bredin from France. The Tribunal ruled (with a dissent from Sir Kenneth Keith) that while France did not breach its obligations by removing Marfart from the island, it did so by failing to order his return. And it was in breach of its obligation by not trying to secure New Zealand's consent to Prieur leaving. France was also in breach for removing Prieur from the island and by failing to order her return. While the Tribunal would not order their return it recommended France and New Zealand to set up a fund to promote close and friendly relations and required France to make an initial contribution of USD 2,000,000. ${ }^{58}$ That was done.

Although France could not be taken to the International Court of Justice, international law was twice vindicated in this dispute, once by negotiation with the assistance and cover from the United Nations and on the second occasion by adjudication by arbitration. The aftermath of such a spectacular event lingered for some time. ${ }^{59}$

58 Rainbow Warrior Case (New Zealand v France) (1990) 40 New Zealand External Relations Review 34.

59 In December 1991 Gerald Andries, who was accused of involvement in the Rainbow Warrior bombing, was arrested in Switzerland. The then Minister of Justice, Hon Doug Graham, announced that extradition proceedings would not be pursued. In April 1991 the French Prime Minister M Rocard had visited New Zealand and it had been agreed then that the matter was at an end: (1991) Keesing's Record of World Events 38676. A lot of warrants had been issued at the time and the execution of warrants against the crew of the Ouvea in Norfolk Island was only narrowly missed by the time taken for forensic tests. The New Zealand law enforcement authorities had found out a lot about the operation and the file was handed to France in order to persuade the Government to face the true facts. Graham Barrett "France: Passion Sank Ship, Book Claims Rainbow Warrior" The Age (Melbourne, 11 October 1993) reported that the late Charles Hernu, France's Minister of Defence at the time of the sinking, had been madly in love with a younger woman at the time and "appeared to lose touch with reality, former aides are reported to have confessed". 


\section{THE PANEL ON THE GAZA FLOTILLA OF 31 MAY 2010}

The best way to introduce the discussion of the Gaza Flotilla incident is to quote from the beginning of the summary of the report itself: ${ }^{60}$

On 31 May 2010 at 4.26 am a flotilla of six vessels was boarded and taken over by Israeli Defence Forces 72 nautical miles from land. The vessels were carrying people and humanitarian supplies. The flotilla had been directed to change course by the Israeli forces who stated that the coast of Gaza was under a naval blockade. Nine passengers lost their lives and many others were wounded as a result of the use of force during the take-over operation by Israeli forces.

The Secretary-General established the Panel of Inquiry on the 31 May 2010 Flotilla Incident on 2 August 2010. The Panel received and reviewed reports of the detailed national investigations conducted by both Turkey and Israel. Turkey established a National Commission of Inquiry to examine the facts of the incident and its legal consequences, which provided an interim and final report to the Panel along with annexes and related material. Israel provided the report of the independent Public Commission that it had established to review whether the actions taken by the State of Israel had been compatible with international law.

The Panel reviewed these reports and further information and clarifications it received in written form and through direct meetings with Points of Contact appointed by each government. In light of the information so gathered, the Panel has examined and identified the facts, circumstances and context of the incident and considered and recommended ways of avoiding similar incidents in the future. In so doing it was not acting as a Court and was not asked to adjudicate on legal liability. Its findings and recommendations are therefore not intended to attribute any legal responsibilities. Nevertheless, the Panel hopes that its report may resolve the issues surrounding the incident and bring the matter to an end.

The Panel's Method of Work provided that the Panel was to operate by consensus, but where, despite best efforts, it was not possible to achieve consensus, the Chair and Vice-Chair could agree on any procedural issue, finding or recommendation. This report has been adopted on the agreement of the Chair and Vice-Chair under that procedure.

The methodology agreed upon and executed by the Panel following the terms of reference and the method of work set out by the Secretary-General was as follows:

- receipt and consideration of interim and final reports of their investigations of the incident from both Israel and Turkey;

60 Geoffrey Palmer and others "Report of the Secretary-General's Panel of Inquiry on the 31 May 2010 Flotilla Incident" (September 2011) < www.un.org> at 3. 
- $\quad$ identification of a person to be the point of contact for each country for communications with the Panel;

- $\quad$ addressing of written questions to the point of contact to clarify information provided and ask for further information; and

- meeting of the Panel with the points of contact to question them and hear oral submissions from them.

This was an inquiry but much of its methodology was diplomatic. It could hardly be anything else. The United Nations has no coercive powers to compel States to provide witnesses to be examined. The matter could not be approached in the manner that a Commission of Inquiry within New Zealand could do so, for example. What was put in front of the inquiry was probed and questioned by asking questions in writing and receiving extensive answers. The Panel was also authorised to put oral questions to the State representatives and it did so. And research into the context could be examined by reading websites, the news media and official United Nations reports on Gaza. Legal research was also conducted. But this was not a judicial inquiry and the Panel was not a court. It employed neither the adversarial techniques of the common law nor the inquisitorial methods of the civilian legal systems. The Panel was empowered to report without the agreement of Israel and Turkey and in the end it did so. The very fact that the Panel was set up to examine the incident ensured a measure of accountability from the States involved; their conduct was scrutinised and analysed. The report was made public. Such inquiries are a relatively new development in the international system. The trend to set up panels is part of a continuing pattern in which the Secretary-General and the United Nations provides a framework for dispute settlement. The Rainbow Warrior ruling by the Secretary-General was an early example of this sort of thing.

Within the United Nations panels of inquiry have been set up for various purposes. The trend appears to be an increasing one since the Agenda for Peace was launched by the Secretary-General in 1992 in which it was stressed that timely and accurate knowledge of the facts was necessary to make preventive diplomacy work. He said: ${ }^{61}$

An increased resort to fact-finding is needed, in accordance with the Charter, initiated either by the Secretary-General, to enable him to meet his responsibilities under the Charter, including Article 99, or by the Security Council or the General Assembly. Various forms may be employed selectively as the situation requires. A request by a State for the sending of a United Nations fact-finding mission to its territory should be considered without undue delay.

Such inquiries do not involve compulsory adjudication and nations can try to keep continuing influence over the issues to some degree. But the independence of those appointed to inquire makes

61 Boutros Boutros-Ghali An Agenda for Peace: Preventive diplomacy, peacemaking and peace-keeping A/47/277 (1992) at [25], reprinted in (1992) 31 ILM 953. 
that difficult. The Gaza Panel was unique in that both nations whose conduct was under investigation were represented on the Panel.

Some of the panels are restricted to fact-finding, some of them conduct wider investigations. Some panels are appointed by the Secretary-General; some are set up by United Nations bodies independent of the Secretary-General. There is an important distinction between Secretary-General Inquiries and Human Rights Council fact-finding missions that have been appointed by States members of the Human Rights Council. The report of the fact-finding mission chaired by retired Justice Goldstone on the Gaza conflict of 2008-2009 was an example of the latter. ${ }^{62}$

In the category appointed by the Secretary-General there are two types. One is those established by the Secretary-General at the direction of the General Assembly or the Security Council. For example the Security Council resolved in October 2004 to establish an International Commission of Inquiry on Darfur to investigate reports of violations of international humanitarian law and human rights law in Darfur. ${ }^{63}$ In 1998 the General Assembly resolved to appoint a Group of Experts for Cambodia to bring about reconciliation and strengthen democracy and address accountability. ${ }^{64}$ In May 2008 the Government of Pakistan requested the Secretary-General to establish an international commission for the purpose of investigating the assassination of Ms Mohtarma Bhutto. ${ }^{65}$ The Secretary-General had a panel examine the human rights abuses arising out of the end of the civil war in Sri Lanka. ${ }^{66}$

Then there are those inquiries established by the Secretary-General himself, acting on his inherent authority. The Flotilla Panel was of this class, although in June 2010 the Security Council took note: ${ }^{67}$

[O]f the statement of the UN Secretary-General on the need to have a full investigation into the matter and it calls for a prompt, impartial, credible and transparent investigation conforming to international standards.

62 Human Rights in Palestine and other Occupied Arab Territories: Report of the United Nations FactFinding Mission on the Gaza Conflict A/HRC/12/48 (2009).

63 Report of the International Commission of Inquiry on Darfur to the United Nations Secretary-General S/2005/60 (2005)

64 Report of the Group of Experts for Cambodia established pursuant to General Assembly Resolution 52/135 A/53/850 (1999).

65 Report of the United Nations Commission of Inquiry into the fact and circumstances of the assassination of former Pakistani Prime Minister Mohtarma Benazir Bhutto S/2010/191 (2010).

66 United Nations "Report of Secretary-General's Panel of Experts on Accountability in Sri Lanka" (31 March 2011) <www.un.org>.

67 The situation in the Middle East, including the Palestinian question S/PRST/2010/9 (2010). 
The Human Rights Council, a body comprising 32 nations, established a fact-finding mission into the Gaza Flotilla as well as the Panel established by the Secretary-General. ${ }^{68}$ To have two United Nations bodies looking at the same incident may appear odd but the Human Rights Council decides what missions it will establish. Israel did not cooperate with the Human Rights mission and provided no information or submission to it.

There is room for some serious scholarly study and analysis of these panels. Inquiries have proliferated in the United Nations over the past 15 years or so. They have some advantages. They can cast light on events and produce a narrative of what actually happened which may be helpful in resolving the dispute. They can clarify issues, provide a narration of facts and suggest where responsibility lies, although they cannot resolve questions of legal liability. They can hold nations to account for their actions. They can bring pressure to bear on nations to change policies. There are downsides as well. The United Nations enjoys no coercive powers to compel witnesses or evidence to be brought before it. Panels are often open to the vagaries of the diplomatic process and pressures. Politics and political methods of the inquiry into the Gaza Flotilla are sometimes employed to pressure and persuade. A panel is not an adjudication nor an arbitration but it has some important elements of these. The law can be canvassed and is always relevant, although it cannot be authoritatively determined.

What became clear to me from the very beginning was that both nations had totally different versions of what happened, how it happened, who was to blame and what the applicable law was. We received an Interim Report from the Turkish Commission of Inquiry quickly - on 1 September 2010. The Turkel Commission from Israel, named after the judge who headed it took much longer that was not received by the United Nations Inquiry until 23 January 2011. The Israeli Commission held public hearings and recorded evidence. It had overseas members and expert consultants. The investigations by Turkey were conducted by public servants and prosecutors. Turkey filed its final report on 11 February 2011.

The first task of the Panel was to try and find out what happened. This proved to be difficult. In the report we set out in analytical summaries the material that was put to the Panel and the evidence tendered in support of it. There were over 700 passengers from 40 countries on board the six vessels. The largest vessel, the Mavi Marmara, was carrying approximately 590 passengers. It was on this vessel alone that casualties resulted from the boarding of Israeli forces. The boarding was resisted.

I shall not here discuss the findings of the Panel or the response to them. These are matters that remain under active consideration at the United Nations itself. What I am interested in for present

68 Report of the International fact-finding mission to investigate violations of international law including international humanitarian and human rights law resulting from the Israeli attacks on the Flotilla of ships carrying humanitarian assistance A/HRC/15/21 (2010). 
purposes is how a panel can contribute to the resolution of such a dispute. The short conclusion is that it can if the nations who are having the dispute want to use it in that way. But whatever techniques are used and whatever findings are made it is the ingredient of political will of ministers from the nations involved that are the critical variable. It is a matter of public record that bilateral negotiations to resolve the issues before the Panel continued alongside the conduct of the Panel's work. The Panel was not involved in any way, but the development clearly created the political context within which it carried out its work. The purpose of the Panel was to identify the facts, circumstances and context of the incident and to recommend ways of avoiding such incidents in the future. A bilateral settlement between the two States involved was devoutly to be wished for and it came close to being achieved.

As matters now stand in the world, disputes can only be resolved where in the judgment of national leaders it is in the national interest that they should be resolved. The United Nations can be a useful catalyst in many ways. But it cannot compel parties either to negotiate or agree. The Secretary-General is often active in stimulating parties to disputes and conflicts to negotiate bilateral solutions. He and his team are often also very involved in more structured and formal types of mediation. Often this is delegated to Special Representatives or Special Envoys such as in Cyprus. And as we have seen there is also a quasi-legal role which has been emerging over the past few decades in which the Secretary-General establishes a framework that has many of the elements of a legal inquiry. Sometimes these are given fully independent powers to make findings. Sometimes such powers are given but in the context of a framework which is specifically designed to incentivise parties to reach agreements through bilateral diplomatic processes which may then be fed back into a panel as formal finding if that is useful or not as the case may be. Some are hybrids using different aspects of these techniques. In the case of the Rainbow Warrior France and New Zealand decided they should resolve the dispute and the Secretary-General provided the framework to allow this to happen and legitimise it in the form of a binding ruling. In the case of Israel and Turkey the countries agreed to the United Nations framework but decided for their own various reasons they could not resolve the dispute despite having had extensive bilateral negotiations after receiving the Panel's draft report and being near to a resolution. So the Panel's report was completed and issued by the Chair and Vice-Chair in the absence of consensus.

\section{THE INTERNATIONAL WHALING COMMISSION}

The dispute at the International Whaling Commission (IWC) was multilateral but in an organisation not within the United Nations framework. It remains a dispute about the future of the International Convention for the Regulation of Whaling, a 1946 instrument that has to some degree been overtaken by time but where no adjustments to the framework can be agreed. ${ }^{69}$ At the time it was framed the Convention was not designed by the whaling nations involved to be anything other

69 International Convention for the Regulation of Whaling 338 UNTS 366 (opened for signature 2 December 1946, entered into force 10 November 1948). 
than a regulatory tool for the sustainable harvesting of whales. It is obvious enough that disputes about changing or modifying international conventions are not susceptible to the same techniques for other categories of dispute. The challenge has been how to adapt the Convention to become a conservation tool in the face of the legal reality that a minority of members resist that change and the Convention can only be amended with their consent. Adjudication cannot resolve such issues although the International Court of Justice has before it a case brought by Australia against Japan on the validity of the use of Japan's whaling methods under art VIII of the Convention. The outcome of this case could influence a great deal the future of the organisation. ${ }^{70}$

Whales are iconic mega-fauna that catch the imagination of the public and are remarkably efficient fund-raisers for NGOs. The public, but more particularly NGOs, exert considerable pressure on the policies of governments and in many respects that fact has made resolution of the dispute at the IWC more difficult. Passions and emotions run high on both sides of this issue. Issues about the need to conserve whales were raised at the Stockholm Conference on the environment in 1972 and 10 years later the IWC adopted the global moratorium on all commercial whaling. The moratorium came into force in $1986 .{ }^{71}$

For eight years from 2002 to 2010 I was New Zealand's Commissioner to the IWC, a remarkably interesting experience but not one that engendered a sense of confidence that the organisation can be made to work effectively. With the support of ministers from 2006 New Zealand was engaged in a heavy diplomatic effort in partnership with the United States to reform the IWC. The effort was not successful, although it came close.

When the moratorium on commercial whaling came into force in 1986 it was regarded as one of the great achievements of modern environmentalism. ${ }^{72}$ It was achieved by a schedule amendment to the Convention that reached the required 75 per cent majority and set the catch limits of whales at zero for commercial whaling. Indigenous people were permitted to continue traditional whaling under quotas set by the Commission with advice from the expert Scientific Committee of the IWC.

The Convention itself was signed in 1946 with only 15 original signatory countries (there are now 89) and had as its objective "to provide for the proper conservation of whale stocks and thus

70 Whaling in the Antarctic (Australia v Japan) (Order setting time limits for pleadings) 13 July 2010. Australia was required to file its memorial by 9 May 2011 and Japan its counter-memorial by 9 March 2012.

71 There are several legal books that are a helpful way to be introduced to the complex law, science and diplomatic history: Alexander Gillespie Whaling Diplomacy: Defining Issues in International Environmental Law (Edward Elgar, Cheltenham, 2005); Patricia Birnie International Regulation of Whaling (Transnational Publication, Dobbs Ferry (New York), 1985); William G Burns and Alexander Gillespie (eds) The Future of Cetaceans in a Changing World (Transnational Publishers, Ardsley (New York), 2003).

72 Edward O Wilson The Future of Life (Little Brown and Co, Boston, 2002) at 26-27. 
make possible the orderly development of the whaling industry." ${ }^{73}$ Despite the good intentions, quota were set far too high and some species of whales became critically endangered so ultimately leading to the moratorium on commercial whaling. The debate was exceedingly acrimonious. The acrimony continued when many of the original members who were whaling countries became staunch conservationists - the United States, Australia, the United Kingdom and New Zealand. The ban that started out as being temporary remained, much to the chagrin of the whaling countries, Japan, Norway and Iceland.

When I began going to the IWC meetings the organisation was paralysed as it had been for years by the chasm between those who wanted to preserve whales and those who wanted to kill them and use them. The bitterness of debates surrounding the commercial whaling moratorium is partly a reflection of a fundamental philosophical conflict between some who insist that the IWC should honour its original purpose of fostering "the orderly development of the whaling industry" 74 and others who object to whaling on ethical grounds. As Schiffman notes: ${ }^{75}$

Whales are a vanguard species in the environmental movement because of their intelligence, beauty, and communal lifestyle. The fact that they are considered to be a consumable resource by some ignites passionate debate about ethics, animal rights, human rights, cultural preservation, cultural relativism, and resource utilization.

Some anti-whaling advocates would oppose commercial whaling even if it were undeniably sustainable for some species in some places.

The fights were rancorous and the organisation did not behave like an international organisation. It was more like an unruly parliament and no doubt that is why my predecessor as Commissioner Jim McLay and myself were selected; parliamentary experience was very relevant. We often used procedural tactics and hard debating to advance New Zealand's interests. And we had a lot of victories that gave satisfaction but looking at the big picture nothing was being achieved. A diplomatic war of attrition was being waged. The organisation could not go on this way.

Norway takes whales perfectly legally; it entered a reservation as it was entitled to do under the Convention when the moratorium was introduced. ${ }^{76}$ Japan did as well but was then persuaded to drop it; afterwards, therefore, it went whaling under art VIII. Iceland left the Convention in 2002. It later rejoined with a reservation against the moratorium. The process by which it rejoined was heavily contested. New Zealand regarded this as a highly dubious legal technique and New Zealand

73 International Convention for the Regulation of Whaling, above n 69, Preambular [7].

74 Ibid.

75 Howard Schiffman "The International Whaling Commission: Challenges from Within and Without" (2004) 10 ILSA J Intl \& Comp L 367 at 370.

76 International Convention for the Regulation of Whaling, above n 69, art V(3). 
does not recognise Iceland as a member. If valid it would mean that any nation could leave the Convention and then rejoin on different terms, producing uncertainty and instability. If the IWC has decided that the conservation of whale stocks requires a moratorium it must be against the object and purpose of the Convention to join with such a reservation. New Zealand's position remains that because of the substance of Iceland's reservation and the manner in which Iceland ultimately gained acceptance Iceland is not considered by New Zealand to be a member of the IWC. ${ }^{77}$

Article VIII provides:

1. Notwithstanding anything contained in this Convention any Contracting Government may grant to any of its nationals a special permit authorizing that national to kill, take and treat whales for purposes of scientific research subject to such restrictions as to number and subject to such other conditions as the Contracting Government thinks fit, and the killing, taking, and treating of whales in accordance with the provisions of this Article shall be exempt from the operation of this Convention. Each Contracting Government shall report at once to the Commission all such authorizations which it has granted. Each Contracting Government may at any time revoke any such special permit which it as granted.

2. Any whales taken under these special permits shall so far as practicable be processed and the proceeds shall be dealt with in accordance with directions issued by the Government by which the permit was granted.

3. Each Contracting Government shall transmit to such body as may be designed by the Commission, in so far as practicable, and at intervals of not more than one year, scientific information available to that Government with respect to whales and whaling, including the results of research conducted pursuant to paragraph 1 of this Article and to Article IV.

4. Recognizing that continuous collection and analysis of biological data in connection with the operations of factory ships and land stations are indispensable to sound and constructive management of the whale fisheries, the Contracting Governments will take all practicable measures to obtain such data.

In the 2009-2010 season as reported to the IWC, 1,867 whales were killed with 825 under Special Permit research whaling under art VIII, 690 under reservation, 336 under indigenous subsistence whaling and 16 under illegal whaling reported to the Commission by Korea. ${ }^{78}$

The international debate on how to reform the IWC was difficult because there were complex issues involving international law, science, and environmental philosophy and intense diplomatic

77 The international law on this subject is complex and is reviewed by Alexander Gillespie, above $\mathrm{n} 71$, at 386-404.

78 International Whaling Commission "Chair's Summary of the Report of the 62nd Annual Meeting" (June 2010) <iwcoffice.org> at Annex K. 
activity over many years. There are three main positions: some nations do not think any whales should be killed under any circumstances; some nations believe whaling is fine as long it is based on the principle of sustainable use; and some nations who think whaling might be acceptable if the Convention had sufficient strength to prevent it getting out of hand and quotas could be effectively policed. No side had the requisite 75 per cent majority to change the rules. The pro-whaling forces were able to secure a resolution known as the St Kitts Declaration passed by a simple majority in 2006 that called for a return to commercial whaling insofar as it could be done in a "controlled and sustainable" fashion. ${ }^{79}$ This led the Commission to make a serious effort to heal itself.

In the months and years that followed the St Kitts Declaration intense and contentious negotiations occurred concerning the future of the IWC. Professional diplomats were called in to offer advice on how the IWC could mend its ways and lower the political temperature. Processes were put in train to try and reach a way through the impasse. At the 2008 IWC meeting a 33 nation Small Working Group was established to work through the issues. This proved to be too big to be effective and in 2009 a smaller Support Group was established to facilitate negotiations with the aim of reaching some compromise that could break the logjam. I was made the chair of this Group and we had many meetings and produced a substantial amount of text on the basis that nothing is agreed until everything is agreed. Gerard van Bohemen, then head of the Legal Division and now Deputy Secretary of Foreign Affairs, led the New Zealand delegation as it was inconsistent with my duties as chair to put forward the New Zealand view.

The compromise proposal was to create a 10 year interim period of stability during which no major decisions would be made that would require nations to change their philosophical or legal position on research whaling, commercial whaling or whaling under reservation. At the same time the proposal would have brought all whaling under full IWC control and the proposal was designed to ensure that catch limits would be set at levels "significantly below the current limits and scientifically determined to be sustainable over the period." 80

The arrangements that had been negotiated could have ensured that the IWC functioned more effectively than it had been doing. At an intersessional meeting in Florida in 2010 I told the delegates that they would have "to swallow a dead rat" if the negotiations were to succeed. The degree of unpalatability had to be about even on each side. What the Support Group could not do was agree on the number of whales to be killed. In particular, the number of whales to be killed by Japan in the Southern Ocean was a sticking point. So the Group wound up its activities in April 2010 without preparing a formal proposal for consideration by the IWC. The Chair and Vice-Chair of the IWC sought to move things forward by offering their own "Proposed Consensus Decision to

79 International Whaling Commission "Chair's Summary of the 58th Annual Meeting" (June 2006) <iwcoffice.org> at 12 .

80 Proposed Consensus Decision to Improve the Conservation of Whales from the Chair and Vice-Chair of the Commission IWC/62/7 (2010), which was presented to IWC members in advance of the 62nd meeting. 
Improve the Conservation of Whales" for consideration at the IWC's June 2010 meeting at Agadir, Morocco. ${ }^{81}$ The central idea was that the IWC would gain control again over the number of whales that would be killed and it would not be in the hands of nations issuing special permits.

The document offered comprised all the work done by the Support Group but the Chair and Vice-Chair filled in the blanks contained in the document about the number of whales to be killed under the arrangements. The total number of whales under all forms of whaling proposed to be killed was 1,819 including 400 Antarctic Minke whales. This was too many for the pro-conservation countries to agree to but it was something the whaling countries would have agreed to. The fact that Australia filed its proceeding in the International Court of Justice not long before the meeting did nothing to assist in reaching a compromise. So the effort of two arduous years and many international meetings upon which extensive resources were expended failed. This has been the repeated fate of almost all initiatives of any importance at the IWC since the moratorium went into force in 1986.

At the 2011 meeting of the IWC the peace process was not advanced and the announcement by Japan in October 2010 that they were returning to whale in the Southern Ocean indicates in my opinion that the stand-off will continue indefinitely, depending on the outcome of the case before the International Court of Justice. One is tempted to reach the conclusion that the issues involved here are irreconcilable. There is a strong prospect in my opinion that as a result of this failure the IWC will collapse and this would not be good news for the whales or the pro-conservation countries. Japan for a number of years has been discussing within the margins of the IWC a new organisation to be formed by the pro-whalers. It all goes to show, unlike the belief of some NGOs, there are no final victories in politics.

\section{CONCLUSION}

As a participant it behoves me to be modest about the accomplishments of the processes for dispute resolution in which I have been involved. And indeed the accomplishments are modest. Not all disputes can be solved and some of those with which I have been involved are in that category. This is an area in which a lot of energy and resources can be expended for little return. One cynic suggested to me that experience at the IWC was good training for dealing with the Middle East. There is truth in the idea that disputes of a deep character with wide gaps between the parties cannot necessarily be solved.

Disputes between nations at the international level are solved or not solved by a wide variety of methods of which adjudication is probably the least prevalent. Political incentives are the key driver and often the range of political positions cannot be reconciled because nations are not prepared to make compromises. The continued extension of the dispute is judged by ministers to have greater political advantage than do the terms upon which a resolution can be obtained.

81 Ibid. 
The shadow of the law hovers as an important influence over every dispute and is frequently a factor in the settlement whether or not the dispute involves an adjudication or arbitration. Mediation, conciliation and negotiation will often involve legal principles and legal positions that are taken as well as the political factors involved.

In the ANZUS dispute the United States and New Zealand did not resolve the dispute concerning what were the legal requirements of the Treaty. The legal issues although pressed were not resolved nor submitted to any dispute settlement process beyond diplomacy. New Zealand said the Treaty did not require much by way of specifics. The United States said we satisfy our obligations to you in a particular way and if you do not accept that then we are suspending our obligations to you. You are now our friend but not our ally. In the end it suited both sides to give the impression there were not any legal issues.

The Rainbow Warrior was a case where the law was clear but its implementation difficult because of extraneous political factors in which the law was not a factor but which were essential in the minds of the decision makers in both countries. These factors bore down upon how the decision looked in each capital. There were highly unpalatable political downsides to be swallowed by both countries. In the end complete resolution was achieved but it took a long time and was highly contentious.

The United Nations was used in the Rainbow Warrior case and a United Nations Panel in the Gaza Flotilla case was established to investigate the incident with the hope this might also encourage a rapprochement between the States concerned. The report produced could have been the catalyst for Israel and Turkey to settle their differences but that could not be achieved despite repeated bilateral attempts to negotiate a settlement in the shadow of the draft report. Turkey has said it will take the issue to the General Assembly and attempt to secure a resolution asking the International Court of Justice for an Advisory Opinion on the legality of the blockade of Gaza at international law. ${ }^{82}$ It is interesting to observe that neither Turkey nor Israel accepts the compulsory jurisdiction of the Court, yet by an indirect route the Court may become seized of the matter.

The impasse reached in the IWC negotiations will be directly before the International Court of Justice when it considers Australia's case against Japan on the validity of its use of art VIII of the Convention in issuing permits for scientific whaling. Both Japan and Australia accept the compulsory jurisdiction of the International Court of Justice.

Whether a dispute can be resolved or not resolved depends not so much on the method of dispute settlement employed as the political incentives at work on the decision makers to resolve the dispute. This is primarily the province of ministers although the advice of officials can be of great

82 On Advisory Opinions see Kenneth James Keith The Extent of the Advisory Jurisdiction of the International Court of Justice (AW Sijthoff, Leyden, 1971). 
help. There are political factors at large in every dispute and general rules about them cannot be propounded in my view.

Clearly the methods of dispute settlement are well known and frequently used. My modest proposal for reform is not new. There is in my view more scope for compulsory dispute settlement by adjudication and arbitration. If that occurred it would add to the political incentives upon decision makers to arrive at a resolution of disputes. Like the prospect of regulation in market economies the threat of compulsory third-party adjudication that cannot be avoided can be a potent force in changing behaviour by altering the incentives. More disputes would be resolved before the prospect of adjudication became a reality. The World Trade Organisation has compulsory adjudication. The Law of the Sea Convention provides for compulsory procedures entailing binding decisions in arts 286 and 287 of Part XV. So does the North American Free Trade Agreement and the European Union.

These precedents are important because they indicate in some contexts at least ministers are prepared to accept third-party adjudication. The resistance to the compulsory jurisdiction of the International Court of Justice and other methods of compulsory adjudication flows from the potential political embarrassment that can come from being on the losing side of the dispute and from losing control of the ingredients of resolution. Surrendering power to others to resolve a dispute by adjudication effectively stops the domestic decision maker being an actor in the resolution. Capacity to influence the outcome is reduced. It is a threat to the capacity of politicians to maintain their power. Adverse proceedings with contending parties can make things worse if they are conducted in public. But arbitration is not subject to this infirmity.

Despite the central role I have put on the political elements of disputes in this paper and the undoubted role of political incentives in dispute settlements I believe strong efforts should be made to strengthen compulsory dispute settlement by adjudication at the international level. Such a feature seems to me to be an essential ingredient of a rule of law at the international level where nations should be under the law not beyond it. The increasing activity of the International Criminal Court shows signs that there is a political appetite for such developments at the international level.

In conclusion we need to recall the observation of Sir Hersch Lauterpacht as long ago as 1933 when he said: ${ }^{83}$

The doctrine of inherent limitations of the judicial process among States is, first and foremost, the work

of international lawyers anxious to give legal expression to the State's claim to be independent of law.

They have sought to do this by the aid of a general theory on the place of law and courts in international society. The practical problem of obligatory arbitration has been linked up with the central problem of the philosophy of the international law and legal philosophy in general.

83 Hersch Lauterpacht The Function of Law in the International Community (Clarendon Press, Oxford, 1933) at 6 . 
The United Nations Rule of Law Project is gathering momentum. ${ }^{84}$ It is to be hoped that the international community can ultimately secure the benefits from the rule of law that many municipal jurisdictions enjoy.

84 Third Annual Report on Strengthening and Coordinating United Nations Rule of Law Activities: Report of the Secretary-General CA/66/133 (2011). 
(2012) 43 VUWLR 